\title{
Estimation of Growth Trends and Impact Assessment of National Food Security Mission on Chickpea Production in India
}

\author{
Nanda Kumar Maharjan* and D.K. Grover \\ Department of Economics \& Sociology, Punjab Agricultural University, Ludhiana-141004, Punjab, India \\ *Corresponding author: anish_maharjan@hotmail.com
}

\begin{abstract}
The present study has been attempted to analyse the growth trends and impact assessment of NFSM-P on area, production and yield of chickpea in major states in India. The study was based on the secondary data pertaining to the year 1970-71 to 2014-15. To estimate growth trends, compound growth function was fitted and change in area, production and yield of chickpea during NFSM-P period (2008-09 to 201415) has been compared with preceding period (1990-91 to 2007-08) for impact assessment of NFSM-P on chickpea in the country. The results of the study indicated that chickpea area in India over the period has almost been stagnating $(0.12 \%$, statistically non-significant). The production of has increased at an annual rate of 1.12 per cent owing to the significant annual increase (1.00\%) in chickpea yield. The results further highlighted emergence of niche area such as Andhra Pradesh and Karnataka in chickpea production while area shrinkage from Haryana, Punjab and Uttar Pradesh was also observed. The yield of chickpea in all the major states of India has shown positive growth during the study period. The effort of the government in the form of NFSM-P has positively impacted area, production and yield of chickpea in the country but increase in production was supported by area addition rather than yield improvement indicating need of technological advancement, improved yield varieties for enhancement of chickpea production in the country.
\end{abstract}

Keywords: Growth trends, National Food Security Mission-Pulses, Impact assessment

The diverse agro-climatic condition in India is favorable for wide range of agricultural crops. Further, with 43 per cent of India's geographical area is being used for agricultural purposes, India holds the significant position in production of numerous agricultural commodities such as millet, rice, wheat, milk and pulses in the world. On the verge of achieving self-sufficiency in domestic agricultural production, India has made remarkable progress in cereals production especially in rice and wheat with the growth in yield by 1.9 per cent and 2.75 per cent per annum respectively during period of 1950-51 to 2013-14 against 0.65 per cent growth in yield of total pulses (Mohanty and Satyasi, 2015). Even though, India is the largest producer of total pulses in the world yet India has also been ranked as the largest importer of pulses. With the domestic pulses production of 17.55 million tonnes from the area of 23.55 million hectare (IIPR, 2015), India has not been able to fulfill increasing pulses demand hence import is inevitable in the country. Further, stagnation in pulses area, increasing demand of protein-rich diet and pulses being consumed as complementary to staple food such as rice and wheat has led to shortfall in domestic supply.

Among pulses grown in India, chickpea is the most major pulse crop with the share of about 51 per cent of total pulses area and 58 per cent of total pulses production. India, with the production of 7.33 million tonnes from the area 8.35 million hectares and 878 $\mathrm{kg} /$ ha yield, is the largest producer of chickpea in the world (IIPR, 2015). Within India, Madhya Pradesh, Rajasthan, Maharashtra, Karnataka, Andhra Pradesh and Uttar Pradesh are the prominent chickpea 
producing states. Traditionally, chickpea was grown as rabi season crop in Uttar Pradesh and Haryana in northern regions of India but with the start of green revolution cereal crops like wheat and rice have replaced chickpea area within these states. In contrast, with the introduction of short-duration improved heat tolerant varieties such as Annigeri and JG-11, chickpea has become popular in Andhra Pradesh and Maharashtra which has been referred as silent chickpea revolution in non-traditional areas (Bantilan et al. 1999; Suhasani et al. 2009). Chickpea, being legume crop, helps in increasing soil fertility and has significant place in crop rotation but the area expansion in not satisfactory over the period. As regards to non-preference for chickpea cultivation among farmers, an attempt was made to rank the major constraints in chickpea production in major producing zones and put forward Helicoverpa armigera as the major constraint followed by lack of knowledge about Integrated Pest Management (IPM), non-availability of good quality seed and Fusarium wilt as other obstacles in expanding chickpea area in India (Chattopadhya and Mohapatra, 2014). To restrain the constraints and boost the pulses production, Government of India has lunched National Food Security MissionPulses (NFSM-P) in 2007-08. Under this program, the main focus was given to increase soil fertility, area expansion under pulses, increase in yield among farmers through technology dissemination and demonstration and proper mobilization of input resources with the help of financial assistance and subsidies. The aim of this mission was to increase pulses production by 2 million tonnes at the end of 2011-12. Further, NFSM-P was continued during $12^{\text {th }}$ Five Year Plan (2012 to 2017) with new target of additional 4 million tonnes of pulses production.

In this context, the present investigation aimed to study the trends in area, production and yield of chickpea in India and to assess the impact of NFSM-P on area, production and yield of chickpea in India.

\section{Database and Methodology}

Data pertaining to area, production and yield of important chickpea growing states were collected from various published secondary sources and for India as a whole for the period of the period of 197071 to 2014-15. The chickpea growing states were selected based on their contribution of more than 95 per cent share with respect area and production. As per the above criteria, Andhra Pradesh, Bihar, Gujarat, Haryana, Karnataka, Madhya Pradesh, Maharashtra, Odisha, Punjab, Rajasthan, Uttar Pradesh and West Bengal were selected. Also, the states which were bifurcated after 1970-71 were merged with the parent states. Hence, area and production of Chhattisgarh, Uttarakhand, Jharkhand and Telangana were combined with Madhya Pradesh, Uttar Pradesh, Bihar and Andhra Pradesh respectively.

For the purpose of trend analysis, overall study period (1970-71 to 2014-15) was divided into three sub-periods, as Period I (1970-71 to 1989-90), PeriodII (1990-91 to 2007-08) and Period-III (2008-09 to 2014-15). Period- I represents pre-Special Food Grain Production Program (SFGPP) on pulses which was implemented during 1988 in order to support National Pulses Development Program. PeriodII represents post-SFGPP. Period- III represents NFSM-P period which was initiated in 2007-08 as centrally sponsored scheme.

\section{Growth Trends}

The growth rates were worked out for different periods by fitting exponential growth function to the time series data.

$$
\begin{aligned}
& Y=a e^{b t} \\
& \text { Or } \ln Y=\ln a+b t
\end{aligned}
$$

Where, $\ln Y=$ Area, production, yield of pulses $t=$ Time (Years); $a=$ intercept; $b=$ growth rate to be estimated

Compound growth rate in per cent $(r)$ was thus estimated as under:

$$
r=(b-1) \times 100
$$

Coefficient of variation (CV) was also calculated for area, production and yield of chickpea for major states and overall India.

\section{Test of significance for difference between mean}

For the detailed study regarding impact of NFSM-P on chickpea, differences of mean area, production and yield between two periods viz. pre-NFSM-P 
period (1990-91 to 2007-08) and NFSM-P period (2008-09 to 2014-15) were calculated and their significance was tested by applying t-test for difference of two independent population means under null hypothesis and alternative hypothesis as follows:

- $\mathrm{H}_{0}: \mu_{2}=\mu_{1}=$ no difference in mean acreage, production and yield of chickpea in preNFSM-P and NFSM-P

- $\mathrm{H}_{1}: \mu_{2}>\mu_{1}=$ mean of acreage, production and yield of chickpea in NFSM-P period is more than pre-NFSM-P period (one-tailed test)

The formula for t-test for difference of two independent population means has been given by,

$$
t=\frac{\left(m_{2}-m_{1}\right)-\left(\mu_{2}-\mu_{1}\right)}{S E\left(m_{2}-m_{1}\right)}
$$

$m_{1}=$ mean of acreage/ production/ yield of chickpea in pre-NFSM-P period

$m_{2}=$ mean of acreage/production/ yield of chickpea in NFSM-P period

$n_{1}=$ number of years in pre-NFSM-P period

$n_{2}=$ number of years in NFSM-P period

$s_{1}=$ standard errors of observations of chickpea in pre-NFSM-P period

$s_{2}=$ standard errors of observations of chickpea in NFSM-P period

Impact of NFSM-P was tested by comparing calculated $\mathrm{t}-$-value with table value at $\left(n_{1}+n_{2}-2\right)$ degree of freedom.

\section{Additive decomposition}

Additive decomposition was carried out for the period 2008-09 to 2014-15. In this method, the total change in production after initiation of NFSM-P program is decomposed into three effects i.e. area effect (\% contribution of area), yield effect (\% contribution of yield) and interaction effect (\% contribution of interaction).

Let $P_{0}$ and $P_{n}$ be production in base year and $\mathrm{n}^{\text {th }}$ year.

$$
\begin{aligned}
& P_{0}=A_{0} \cdot Y_{0} \\
& P_{n}=A_{n} \cdot Y_{n}
\end{aligned}
$$

Where $A_{0}, A_{n}$ represent area, $Y_{0}, Y_{n}$ represent yield for the base year and $n^{\text {th }}$ year, respectively. The base year and $n^{\text {th }}$ year observations are triennium averages.

Let $\Delta A, \Delta P$ and $\Delta Y$ be the change in area, production and yield of the chickpea after a $\mathrm{n}^{\text {th }}$ time period, so we have,

$$
P_{0}+\Delta P=\left(A_{0}+\Delta A\right)\left(\mathrm{Y}_{0}+\Delta Y\right)
$$

Therefore, we have,

$$
\Delta P=\Delta A Y_{0}+A_{0} \Delta Y+\Delta A \Delta Y
$$

Thus, the total differential production is composed of three components,

$$
\begin{aligned}
& \Delta A Y_{0}=\text { Area effect } \\
& A_{0} \Delta Y=\text { Yield effect } \\
& \Delta A \Delta Y=\text { Interaction effect }
\end{aligned}
$$

\section{RESULTS AND DISCUSSION}

The results have been discussed under four subheads. These are (1) State-wise share of area, production and yield of chickpea in India, (2) Growth trends in area, production and yield of chickpea in India, (3) Impact of NFSM-P on area, production and yield of chickpea in India and (4) Relative contribution of area and yield in production of chickpea during NFSM-P period

\section{(I) State-wise share of area, production and yield of chickpea in India}

\section{State-wise share of chickpea area}

Uttar Pradesh (26.50\%), Madhya Pradesh (20.65\%) and Rajasthan $(20.63 \%)$ were the major contributor of the total chickpea area during 1970-71 (Table 1). The highest reduction in chickpea area share was recorded in Haryana and Punjab from 13.34 per cent and 4.57 per cent in 1970-71 to 0.97 per cent and 0.05 per cent respectively in 2014-15 whereas, Andhra Pradesh, Karnataka and Maharashtra showed significant expansion during the same period. After more than four decades, Madhya Pradesh and Rajasthan remained the significant contributor of chickpea area while Uttar Pradesh's area share reduced significantly. Maharashtra (14.32\%) and Karnataka (11.20\%) has emerged as 
Table 1: State-wise chickpea acreage in India, $1970-71$ to 2014-15 Area (000’ ha)

\begin{tabular}{|c|c|c|c|c|c|c|c|c|c|c|}
\hline States & $1970-71$ & 1975-76 & $1980-81$ & $1985-86$ & 1990-91 & 1995-96 & 2000-01 & 2005-06 & 2010-11 & 2014-15 \\
\hline \multirow{2}{*}{ Andhra Pradesh } & 73.0 & 87.8 & 45.6 & 49.0 & 88.4 & 112.9 & 201.0 & 394.0 & 586.0 & 401.0 \\
\hline & $(0.93)$ & (1.06) & $(0.69)$ & $(0.63)$ & (1.18) & (1.59) & (3.87) & (5.69) & (6.36) & $(4.80)$ \\
\hline \multirow{2}{*}{ Bihar } & 244.4 & 245.1 & 195.8 & 190.6 & 167.7 & 140.8 & 76.2 & 92.4 & 130.0 & 220.7 \\
\hline & (3.12) & (2.95) & (2.98) & (2.44) & (2.23) & (1.98) & (1.47) & (1.33) & (1.41) & (2.64) \\
\hline \multirow{2}{*}{ Gujarat } & 52.9 & 77.2 & 63.5 & 80.8 & 170.2 & 82.4 & 17.0 & 167.0 & 198.0 & 182 \\
\hline & $(0.67)$ & $(0.93)$ & $(0.97)$ & $(1.04)$ & (2.26) & (1.16) & $(0.33)$ & (2.41) & (2.15) & (2.18) \\
\hline \multirow{2}{*}{ Haryana } & 1046 & 1106.2 & 741.0 & 758.0 & 649.0 & 377.0 & 125.0 & 130.0 & 112.0 & 81.0 \\
\hline & (13.34) & (13.30) & (11.26) & $(9.72)$ & (8.63) & (5.29) & (2.41) & (1.88) & $(1.22)$ & $(0.97)$ \\
\hline \multirow{2}{*}{ Karnataka } & 159.7 & 191.8 & 143.5 & 191.0 & 229.5 & 293.4 & 369.5 & 418.0 & 960.0 & 935.0 \\
\hline & (2.04) & $(2.31)$ & (2.18) & (2.45) & (3.05) & $(4.12)$ & (7.12) & $(6.03)$ & (10.42) & (11.20) \\
\hline \multirow{2}{*}{ Madhya Pradesh } & 1619.1 & 1917.3 & 1806.7 & 2282.0 & 2462.1 & 2660.2 & 2118.5 & 2798.5 & 3364.0 & 3133.6 \\
\hline & (20.65) & (23.04) & (27.46) & (29.26) & (32.74) & $(37.36)$ & $(40.82)$ & $(40.38)$ & (36.53) & (37.53) \\
\hline \multirow{2}{*}{ Maharashtra } & 368.6 & 456.3 & 429.1 & 533.8 & 672.9 & 717.1 & 676.0 & 1020.0 & 1423.0 & 1196.0 \\
\hline & $(4.70)$ & (5.48) & $(6.52)$ & $(6.84)$ & (8.95) & (10.07) & (13.03) & (14.72) & (15.45) & (14.32) \\
\hline \multirow{2}{*}{ Odisha } & 21.5 & 30.7 & 50.0 & 42.2 & 45.8 & 38.2 & 21.0 & 35.3 & 42.0 & 60.0 \\
\hline & $(0.27)$ & $(0.37)$ & $(0.76)$ & $(0.54)$ & $(0.61)$ & $(0.54)$ & $(0.40)$ & $(0.51)$ & $(0.46)$ & $(0.72)$ \\
\hline \multirow{2}{*}{ Punjab } & 357.9 & 381.2 & 258.0 & 108.0 & 60.7 & 19.5 & 7.7 & 4.0 & 3.1 & 4.0 \\
\hline & $(4.57)$ & $(4.58)$ & $(3.92)$ & $(1.38)$ & $(0.81)$ & $(0.27)$ & $(0.15)$ & $(0.06)$ & $(0.03)$ & $(0.05)$ \\
\hline \multirow{2}{*}{ Rajasthan } & 1617.5 & 1952.4 & 1225.4 & 1940.7 & 1652.7 & 1620.3 & 672.6 & 1081.9 & 1783 & 1256.3 \\
\hline & (20.63) & $(23.47)$ & (18.62) & $(24.88)$ & (21.98) & (22.76) & (12.96) & $(15.61)$ & (19.36) & (15.05) \\
\hline \multirow{2}{*}{ Uttar Pradesh } & 2077.9 & 1725.5 & 1495.9 & 1534.7 & 1275.3 & 1005.9 & 834.1 & 740.6 & 570.5 & 589.7 \\
\hline & $(26.50)$ & (20.74) & (22.73) & (19.68) & (16.96) & (14.13) & (16.07) & (10.69) & (6.19) & (7.06) \\
\hline \multirow{2}{*}{ West Bengal } & 155.1 & 98.7 & 96.2 & 68.7 & 25.6 & 31.5 & 54.7 & 40.0 & 22.0 & 27.0 \\
\hline & (1.98) & (1.19) & (1.46) & $(0.88)$ & $(0.34)$ & $(0.44)$ & $(1.05)$ & $(0.58)$ & $(0.24)$ & $(0.32)$ \\
\hline \multirow{2}{*}{ Rest of India } & 46.4 & 49.8 & 29.3 & 20.5 & 20.1 & 20.8 & 16.7 & 8.3 & 16.4 & 263.7 \\
\hline & $(0.59)$ & $(0.60)$ & $(0.45)$ & $(0.26)$ & $(0.27)$ & $(0.29)$ & $(0.32)$ & $(0.12)$ & $(0.18)$ & (3.16) \\
\hline \multirow{2}{*}{ India } & 7840 & 8320 & 6580 & 7800 & 7520 & 7120 & 5190 & 6930 & 9210 & 8350 \\
\hline & (100) & (100) & (100) & (100) & (100) & (100) & (100) & (100) & (100) & (100) \\
\hline
\end{tabular}

Figures in the parenthesis indicate percentages to respective values.

the major chickpea cultivating states in recent years. In Indian scenario, chickpea area recorded marginal increase from 7840 thousand hectares in 1970-71 to 8350 thousand hectares 2014-15 while the record highest of 9210 thousand hectares chickpea area was recorded in 2010-11.

\section{State-wise share of chickpea production}

Table 2 showed that Uttar Pradesh, Rajasthan and Madhya Pradesh were the highest producers of chickpea during 1970-71 with the total contribution of about 69 per cent of total production in India. The highest of 1544.6 thousand tonnes with 29.70 per cent share of total chickpea production was produced in Uttar Pradesh while Andhra Pradesh $(0.48 \%)$, Gujarat $(0.84 \%)$ and Odisha $(0.25 \%)$ have minor contribution in chickpea basket of India. Over the period, the chickpea production in states namely, Andhra Pradesh, Karnataka and Maharashtra increased significantly while decreasing trends were observed in Haryana, Punjab, Rajasthan and Uttar Pradesh. In Punjab scenario, the share of chickpea production weakened after 1975-76 from 6.39 per cent to 0.07 thousand tonnes in 2014-15. Bihar and Odisha displayed the stable share of chickpea production over the period. The main reason of production shift of chickpea across states might be because of the shift in area. Even though there was significant decrease in chickpea production share of Rajasthan from 22.99 per cent in 1970-71 to 12.43 per cent in 2014-15, Rajasthan remained as the second major chickpea producing states after 
Table 2: State-wise chickpea production in India, 1970-71 to 2014-15 (Production (000’ Tonnes))

\begin{tabular}{|c|c|c|c|c|c|c|c|c|c|c|}
\hline States & 1970-71 & 1975-76 & $1980-81$ & $1985-86$ & 1990-91 & 1995-96 & 2000-01 & 2005-06 & $2010-11$ & 2014-15 \\
\hline Andhra & 24.8 & 36.6 & 13.6 & 17.4 & 56.9 & 71.1 & 229.0 & 627.0 & 724.0 & 472.0 \\
\hline Pradesh & $(0.48)$ & $(0.62)$ & $(0.31)$ & $(0.30)$ & (1.06) & (1.43) & (5.93) & (11.20) & $(8.79)$ & (6.44) \\
\hline \multirow{2}{*}{ Bihar } & 174.2 & 134.8 & 140.6 & 160.0 & 157.8 & 91.6 & 78.7 & 80.6 & 129.0 & 243.9 \\
\hline & (3.35) & (2.29) & (3.25) & (2.76) & (2.94) & $(1.84)$ & $(2.04)$ & $(1.44)$ & $(1.57)$ & (3.33) \\
\hline \multirow{2}{*}{ Gujarat } & 43.9 & 53.6 & 47.0 & 45.5 & 115.8 & 50.1 & 9.0 & 142.0 & 232.0 & 206.0 \\
\hline & $(0.84)$ & $(0.91)$ & (1.09) & $(0.79)$ & (2.16) & (1.01) & $(0.23)$ & $(2.54)$ & $(2.82)$ & (2.81) \\
\hline \multirow{2}{*}{ Haryana } & 774.0 & 907.0 & 466.0 & 622.0 & 469.0 & 381.0 & 80.0 & 72.0 & 110.0 & 81.0 \\
\hline & (14.88) & (15.43) & (10.76) & (10.74) & (8.75) & $(7.65)$ & $(2.07)$ & (1.29) & (1.33) & (1.11) \\
\hline \multirow{2}{*}{ Karnataka } & 62.1 & 88.8 & 57.6 & 60.5 & 68.5 & 141.3 & 239.4 & 229.0 & 601.0 & 666.0 \\
\hline & (1.19) & $(1.51)$ & (1.33) & $(1.04)$ & $(1.28)$ & $(2.84)$ & $(6.20)$ & $(4.09)$ & (7.29) & $(9.09)$ \\
\hline Madhya & 855.7 & 1226.4 & 1063.3 & 1557.4 & 1891.9 & 1988.4 & 1692.4 & 2534.6 & 2928.0 & 3254.4 \\
\hline Pradesh & (16.46) & (20.86) & (24.56) & (26.90) & (35.30) & (39.93) & $(43.84)$ & $(45.26)$ & (35.53) & $(44.40)$ \\
\hline \multirow{2}{*}{ Maharashtra } & 98.5 & 185.2 & 150.2 & 175.6 & 357.8 & 376.0 & 351.0 & 705.0 & 1323.0 & 834.0 \\
\hline & (1.89) & (3.15) & $(3.47)$ & (3.03) & (6.68) & (7.55) & (9.09) & (12.59) & (16.06) & (11.38) \\
\hline \multirow{2}{*}{ Odisha } & 12.8 & 14.9 & 26.2 & 25.5 & 32.6 & 25.5 & 10.0 & 22.8 & 31.0 & 50.0 \\
\hline & $(0.25)$ & $(0.25)$ & $(0.61)$ & $(0.44)$ & $(0.61)$ & $(0.51)$ & $(0.26)$ & $(0.41)$ & $(0.38)$ & (0.68) \\
\hline \multirow{2}{*}{ Punjab } & 284.0 & 376.0 & 150.0 & 98.4 & 45.2 & 17.4 & 7.3 & 3.0 & 3.8 & 5.4 \\
\hline & $(5.46)$ & (6.39) & $(3.46)$ & $(1.70)$ & $(0.84)$ & $(0.35)$ & $(0.19)$ & $(0.05)$ & $(0.05)$ & $(0.07)$ \\
\hline \multirow{2}{*}{ Rajasthan } & 1195.4 & 1498.3 & 854.3 & 1623.1 & 1011.0 & 1090.3 & 396.6 & 478.9 & 1601.0 & 911.1 \\
\hline & (22.99) & (25.48) & (19.73) & (28.03) & (18.86) & (21.89) & (10.27) & $(8.55)$ & (19.43) & (12.43) \\
\hline \multirow{2}{*}{ Uttar Pradesh } & 1544.6 & 1250.1 & 1288.2 & 1326.7 & 1121.6 & 698.3 & 703.7 & 661.6 & 530.4 & 368.3 \\
\hline & (29.70) & $(21.26)$ & (29.75) & (22.91) & (20.93) & (14.02) & (18.23) & (11.81) & $(6.44)$ & (5.02) \\
\hline \multirow{2}{*}{ West Bengal } & 103.3 & 78.6 & 55.6 & 59.8 & 15.0 & 34.4 & 50.2 & 36.5 & 25.0 & 32.0 \\
\hline & (1.99) & (1.34) & $(1.28)$ & (1.03) & $(0.28)$ & $(0.69)$ & $(1.30)$ & $(0.65)$ & $(0.30)$ & $(0.44)$ \\
\hline \multirow{2}{*}{ Rest of India } & 26.7 & 29.7 & 17.4 & 18.1 & 16.9 & 14.6 & 12.7 & 7.0 & 1.8 & 205.9 \\
\hline & $(0.51)$ & $(0.51)$ & $(0.40)$ & $(0.31)$ & $(0.32)$ & $(0.29)$ & $(0.33)$ & $(0.12)$ & $(0.02)$ & (2.81) \\
\hline \multirow{2}{*}{ India } & 5200 & 5880 & 4330 & 5790 & 5360 & 4980 & 3860 & 5600 & 8240 & 7330 \\
\hline & (100) & (100) & (100) & (100) & (100) & (100) & (100) & (100) & (100) & (100) \\
\hline
\end{tabular}

Figures in the parenthesis indicate percentages to respective values.

Madhya Pradesh (44.40\%) during 2015. In Indian context, net increase of 2130 thousand tonnes over more than four decades could be observed with the highest production of 8240 thousand tonnes in 2010-11.

\section{State-wise chickpea yield}

Large variation in yield across states was prevalent during 1970-71 with the highest of $830 \mathrm{~kg}$ per hectare in Gujarat and the lowest being $267 \mathrm{~kg}$ per hectare in Maharashtra (Table 3). Over the period, the improvement in yield in all states has been witnessed except in Rajasthan and Uttar Pradesh where marginal decrease in yield from $739 \mathrm{~kg}$ per hectare to $725 \mathrm{~kg}$ per hectare and $743 \mathrm{~kg}$ per hectare to $625 \mathrm{~kg}$ per hectare respectively was observed during the study period. Andhra Pradesh and Maharashtra yield increased more than three-fold over four decades. Even though yield across major chickpea cultivating states has increased, average yield in India as a whole showed tenuous increase from $663 \mathrm{~kg}$ per hectare in 1970-71 to $878 \mathrm{~kg}$ per hectare in 2014-15 with the highest of $895 \mathrm{~kg}$ per hectare during 2010-11.

\section{(II) Growth trends in area, production and yield of chickpea in India}

\section{State-wise chickpea acreage trends}

During Period I, all the major states in northern and eastern zones exhibited statistically significant negative growth rate except in Odisha which 
Table 3: State-wise chickpea yield in India, 1970-71 to 2014-15 (Yield (kg/ha))

\begin{tabular}{ccccccccccc}
\hline States & $\mathbf{1 9 7 0 - 7 1}$ & $\mathbf{1 9 7 5 - 7 6}$ & $\mathbf{1 9 8 0 - 8 1}$ & $\mathbf{1 9 8 5 - 8 6}$ & $\mathbf{1 9 9 0 - 9 1}$ & $\mathbf{1 9 9 5 - 9 6}$ & $\mathbf{2 0 0 0 - 0 1}$ & $\mathbf{2 0 0 5 - 0 6}$ & $\mathbf{2 0 1 0 - 1 1}$ & $\mathbf{2 0 1 4 - 1 5}$ \\
\hline Andhra Pradesh & 340 & 417 & 298 & 355 & 644 & 630 & 1139 & 1591 & 1235 & 1177 \\
Bihar & 713 & 550 & 718 & 839 & 941 & 651 & 1033 & 872 & 992 & 1105 \\
Gujarat & 830 & 694 & 740 & 563 & 680 & 608 & 529 & 850 & 1172 & 1132 \\
Haryana & 740 & 820 & 629 & 821 & 723 & 1011 & 640 & 554 & 982 & 1000 \\
Karnataka & 389 & 463 & 401 & 317 & 298 & 482 & 648 & 548 & 626 & 712 \\
Madhya Pradesh & 529 & 640 & 589 & 682 & 768 & 747 & 799 & 906 & 870 & 1039 \\
Maharashtra & 267 & 406 & 350 & 329 & 532 & 524 & 519 & 691 & 930 & 697 \\
Odisha & 595 & 485 & 524 & 604 & 712 & 668 & 476 & 646 & 738 & 833 \\
Punjab & 794 & 986 & 581 & 911 & 745 & 892 & 948 & 750 & 1226 & 1350 \\
Rajasthan & 739 & 767 & 697 & 836 & 612 & 673 & 590 & 443 & 898 & 725 \\
Uttar Pradesh & 743 & 724 & 861 & 864 & 879 & 694 & 844 & 893 & 930 & 625 \\
West Bengal & 666 & 796 & 578 & 870 & 586 & 1092 & 918 & 913 & 1136 & 1185 \\
India & 663 & 707 & 658 & 742 & 713 & 699 & 744 & 808 & 895 & 878 \\
\hline
\end{tabular}

Table 4: State-wise trends (CGR \%) of chickpea acreage in India, 1970-71 to 2014-15

\begin{tabular}{|c|c|c|c|c|}
\hline States & $\begin{array}{c}\text { Period I } \\
(1970-71 \text { to } 1989-90)\end{array}$ & $\begin{array}{c}\text { Period II } \\
\text { (1990-71 to 2007-08) }\end{array}$ & $\begin{array}{c}\text { Period III } \\
(2008-09 \text { to 2014-15) }\end{array}$ & $\begin{array}{c}\text { Overall Period } \\
(1970-71 \text { to } 2014-15)\end{array}$ \\
\hline \multicolumn{5}{|l|}{ Northern Zone } \\
\hline Haryana & $-4.69^{* *}$ & $-10.55^{* *}$ & -7.38 & -6.76 \\
\hline Punjab & $-9.94^{* *}$ & $-13.84^{* *}$ & -1.37 & $-12.89^{* *}$ \\
\hline Uttar Pradesh & $-2.17^{* *}$ & $-3.61^{* *}$ & 0.37 & $-3.08^{* *}$ \\
\hline \multicolumn{5}{|l|}{ Southern Zone } \\
\hline Andhra Pradesh & $-1.77^{* *}$ & $14.27^{* *}$ & -4.51 & $6.63^{* *}$ \\
\hline Karnataka & $1.96^{* *}$ & $5.73^{* *}$ & 2.58 & $4.70^{* *}$ \\
\hline \multicolumn{5}{|l|}{ Eastern Zone } \\
\hline Bihar & $-2.50^{* *}$ & $-3.03^{* *}$ & $10.32^{* *}$ & $-1.63^{* *}$ \\
\hline Odisha & $4.35^{* *}$ & -0.83 & $5.42^{*}$ & $0.56^{*}$ \\
\hline West Bengal & $-5.77^{* *}$ & $4.06^{* *}$ & $3.83^{* *}$ & $-3.77^{* *}$ \\
\hline \multicolumn{5}{|l|}{ Western Zone } \\
\hline Gujarat & 2.50 & 1.64 & 4.49 & $2.86^{* *}$ \\
\hline Maharashtra & $2.83^{* *}$ & $4.07^{* *}$ & 2.11 & $3.19^{* *}$ \\
\hline Rajasthan & -1.41 & -3.04 & 4.35 & $-0.80^{* *}$ \\
\hline \multicolumn{5}{|l|}{ Central Zone } \\
\hline Madhya Pradesh & $1.17^{* *}$ & $1.60^{* *}$ & 0.43 & $1.53^{* *}$ \\
\hline India & $-0.90^{* *}$ & 0.24 & 1.74 & 0.12 \\
\hline
\end{tabular}

Note: ${ }^{* *}$ and ${ }^{*}$ indicate significance at 1 and 5 percent level respectively.

experienced statistically significant positive growth rate of 4.35 per cent per annum (Table 4 ). The highest negative growth rate was observed in Punjab with 9.94 per cent per annum which was significant at one per cent level. The main reason for the reduction of chickpea area in northern and eastern zones of India might be because of introduction of new technology, especially for wheat and rice, introduced during green revolution. With the prevalent negative growth rate in major states, India experienced significant negative growth by 0.90 per cent per annum during this period. Similar growth trends continued during Period-II, with the highest decrease in Punjab by 13.84 per cent per annum but West Bengal area expanded by 4.06 per cent per annum during this period which was negative in preceding period. The growth rates of chickpea area in southern and central zones were encouraging 
with the maximum of 14.27 per cent per annum growth rate in Andhra Pradesh while Maharashtra also recorded significant growth rate of 4.07 per cent per annum. During Period-III, chickpea area in eastern, western and central zones showed positive increase with the maximum growth rate of 10.32 per cent in Bihar. The statistically non-significant decline in area was noticed in Haryana and Punjab but statistically non-significant positive increase by 0.37 per cent annum was noticed in Uttar Pradesh. This period was marked by various interventions by the government, hence increase in total chickpea area in India was noticed as compared with previous periods. During Overall Period, southern, central and western zones except in Rajasthan recorded statistically significant positive growth in chickpea area while negative growth in area was prevalent in all major states in northern zones. The highest of 6.63 per cent per annum followed by 4.70 per cent per annum was recorded in Andhra Pradesh and Karnataka revealed that chickpea area has been shifting to southern zone of India in recent years. India experienced marginal growth of 0.12 per cent per annum since 1970-71.

\section{State-wise chickpea production trends}

Chickpea production during Period-I was marked by heavy reduction in production in northern and eastern zones of India except in Odisha where significant increase in production by 5.91 per cent per annum was observed (Table 5). Punjab (-11.32\%) and West Bengal (-5.19) showed the highest reduction in production which might be contributed by increasing yield of wheat and rice after green revolution during this period while Maharashtra and Madhya Pradesh production increased by 5.64 per cent per annum and 2.56 per cent per annum respectively. During Period-II, significant declining trends continued in entire major states northern zone while remarkable increase in production in Andhra Pradesh (20.27\%) and Karnataka (8.11\%) of southern zone was recorded. Statistically significant increase in production in West Bengal (5.19\%), Maharashtra (5.59\%) and Madhya Pradesh (1.53\%) were also explored during this period. During Period-III, statistically non-significant negative growth was noticed in Haryana and Uttar Pradesh which was marked by statistically significant negative growth in preceding periods. The production of chickpea in Andhra Pradesh also decreased by 6.04 per cent per annum which enjoyed significant positive growth rate in preceding period whilst eastern, western and central zones showed the positive increase which might be due to the response of various government program and schemes implemented during this period. In Overall Period, statistically significant

Table 5: State-wise trends (CGR \%) of chickpea production in India, 1970-71 to 2014-15

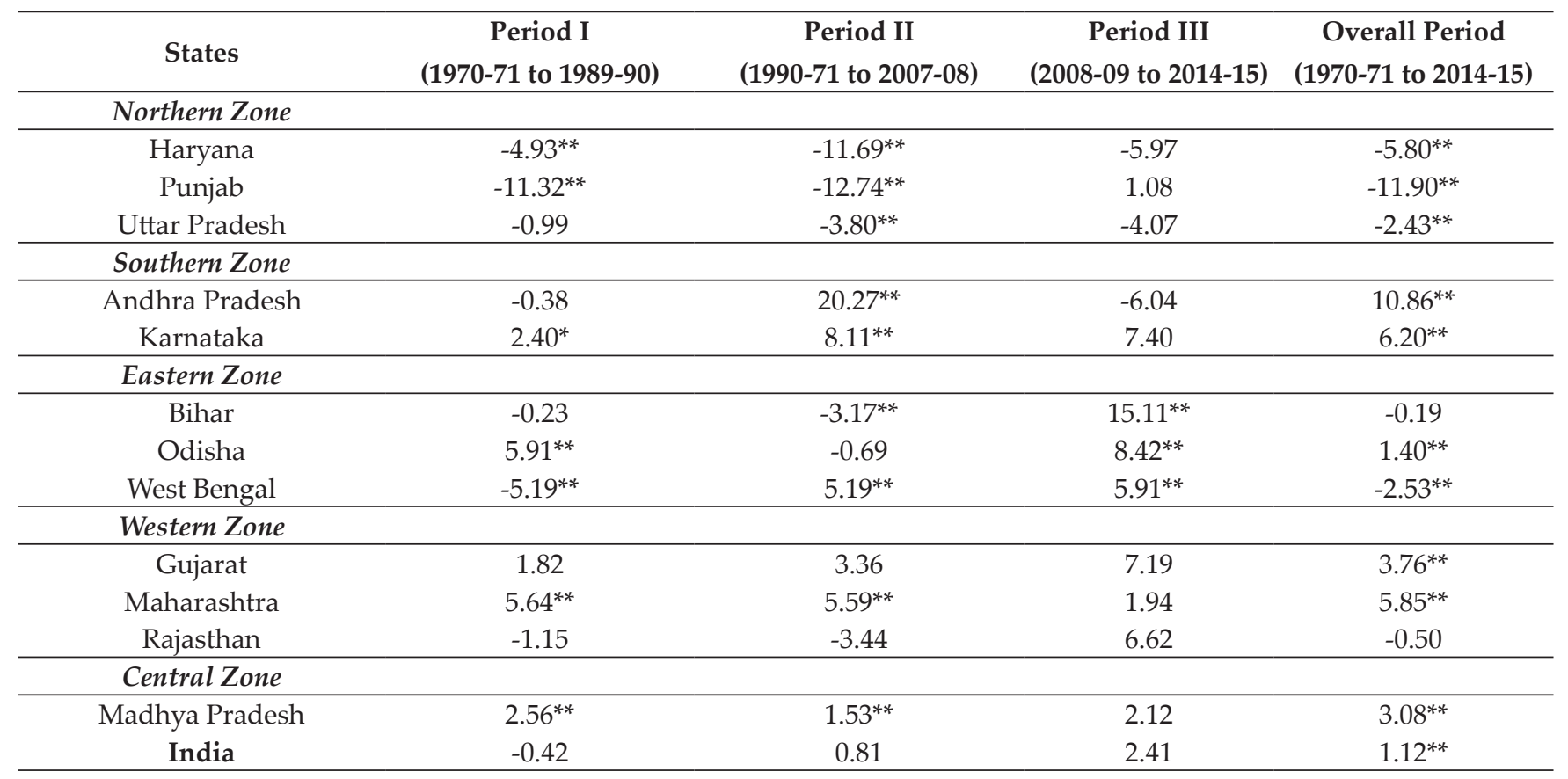

Note: ** and * indicate significance level at 1 and 5 percent level respectively. 
positive growth in chickpea production by 1.12 per cent per annum was recorded in India which was contributed by statistically significant increase in production in Andhra Pradesh (10.86\%), Karnataka $(6.20 \%)$, Maharashtra (5.58\%), Gujarat (3.76\%), Madhya Pradesh (3.08\%) and Odisha (1.40\%).

\section{State-wise chickpea yield trends}

State-wise trends of chickpea yield have been depicted in Table 6. The table revealed that during Period-I, the yield of chickpea has increased in all the major states with the highest increase of 2.74 per cent per annum in Maharashtra except in Haryana $(0.25 \%)$,

Punjab (1.54\%) and Gujarat (0.66\%) but was found statistically non-significant. During Period-II, decreasing trends in yield continued in Haryana but Punjab and Gujarat demonstrated statistically significant positive growth. At the same time, statistically significant increase in yield in southern zone was observed with the highest of 5.25 per cent in Andhra Pradesh. With the statistically significant increase in yield in Punjab (1.27\%), Gujarat (1.69\%), Maharashtra (1.45\%) and major states in southern zones, India experienced growth of 0.57 per cent per annum during this period. During Period-III, noticeable improvement in yield in all states of eastern zone was observed while other zones in India recorded non-significant positive growth except in Uttar Pradesh (4.42\%), Andhra Pradesh $(1.61 \%)$ and Maharashtra $(0.17 \%)$ where negative growth was confirmed. Yield in Overall Period was marked by statistically significant increase in all across India excluding Rajasthan where statistically non-significant increase of 0.30 per cent per annum was observed. India recorded the marginal growth of 1 per cent per annum over more than four decades.

(III) Impact of NFSM-P on area, production and yield of chickpea in major states of India

After initiation of NFSM-P, significant impact on overall area, production and yield after NFSM-P could be seen in Andhra Pradesh, Bihar, Gujarat, Karnataka Madhya Pradesh, Maharashtra and Odisha while statistically significant positive impact on yield was also observed in all the states except in Uttar Pradesh (Table 7). Among the states, the highly significant growth in area and yield was observed in Bihar of 10.32 per cent per annum and 4.35 per cent per annum respectively thus enhancement in production by 15.11 per cent per annum after start of the mission. Major impact of NFSM-P in increasing area, production and yield has been noticed in major states in southern

Table 6: State-wise trends (CGR \%) of chickpea yield in India, 1970-71 to 2014-15

\begin{tabular}{|c|c|c|c|c|}
\hline States & $\begin{array}{c}\text { Period I } \\
(1970-71 \text { to } 1989-90)\end{array}$ & $\begin{array}{c}\text { Period II } \\
\text { (1990-71 to 2007-08) }\end{array}$ & $\begin{array}{c}\text { Period III } \\
\text { (2008-09 to 2014-15) }\end{array}$ & $\begin{array}{c}\text { Overall Period } \\
\text { (1970-71 to 2014-15) }\end{array}$ \\
\hline \multicolumn{5}{|l|}{ Northern Zone } \\
\hline Haryana & -0.25 & -1.27 & 1.53 & $1.03^{* *}$ \\
\hline Punjab & -1.54 & $1.27^{* *}$ & $2.50^{*}$ & $1.14^{* *}$ \\
\hline Uttar Pradesh & $1.20^{*}$ & -0.19 & -4.42 & $0.67^{* *}$ \\
\hline \multicolumn{5}{|l|}{ Southern Zone } \\
\hline Andhra Pradesh & $1.41^{*}$ & $5.25^{* *}$ & -1.61 & $3.96^{* *}$ \\
\hline Karnataka & 0.44 & $2.25^{* *}$ & 4.70 & $1.43^{* *}$ \\
\hline \multicolumn{5}{|l|}{ Eastern Zone } \\
\hline Bihar & $2.32^{* *}$ & 0.14 & $4.35^{* *}$ & $1.46^{* *}$ \\
\hline Odisha & $1.50^{* *}$ & 0.13 & $2.84^{* *}$ & $0.83^{* *}$ \\
\hline West Bengal & 0.62 & 1.09 & $2.00^{* *}$ & $1.29^{* *}$ \\
\hline \multicolumn{5}{|l|}{ Western Zone } \\
\hline Gujarat & -0.66 & $1.69^{*}$ & 2.59 & $0.87^{* *}$ \\
\hline Maharashtra & $2.74^{* *}$ & $1.45^{*}$ & -0.17 & $2.58^{* *}$ \\
\hline Rajasthan & 0.26 & -0.14 & 2.17 & 0.30 \\
\hline \multicolumn{5}{|l|}{ Central Zone } \\
\hline Madhya Pradesh & 0.84 & 0.47 & 1.70 & $1.53^{* *}$ \\
\hline India & 0.49 & $0.57^{*}$ & 0.65 & $1.00^{* *}$ \\
\hline
\end{tabular}

Note: ${ }^{* *}$ and ${ }^{*}$ indicate significance level at 1 and 5 percent level respectively. 
Table 7: Impact of NFSM-Pulses on area, production and yield of chickpea in major states of India ('000 ha, ‘000 tonnes, $\mathrm{kg} / \mathrm{ha}$ )

\begin{tabular}{|c|c|c|c|c|c|c|c|c|c|}
\hline \multirow{2}{*}{ States } & \multirow{2}{*}{ Variables } & \multicolumn{3}{|c|}{$\begin{array}{c}\begin{array}{c}\text { Before NFSM-Pulses } \\
\text { (1990-91 to 2007-08) }\end{array} \\
\text { Estimates of }\end{array}$} & \multicolumn{3}{|c|}{$\begin{array}{c}\begin{array}{c}\text { After NFSM-Pulses } \\
\text { (2008-09 to 2014-15) }\end{array} \\
\text { Estimates of }\end{array}$} & \multirow{2}{*}{$\begin{array}{l}\text { NFSM- } \\
\text { Pulses } \\
\text { Impact } \\
\left(\mathrm{m}_{2}-\mathrm{m}_{1}\right)\end{array}$} & \multirow{2}{*}{$\begin{array}{c}\text { t-value } \\
\text { (Cal.) }\end{array}$} \\
\hline & & $\begin{array}{c}\text { Mean } \\
\left(\mathrm{m}_{1}\right)\end{array}$ & $\mathrm{CV}$ & CGR (\%) & $\begin{array}{c}\text { Mean } \\
\left(\mathrm{m}_{2}\right)\end{array}$ & $\mathrm{CV}$ & CGR (\%) & & \\
\hline \multicolumn{10}{|l|}{ Northern Zone } \\
\hline \multirow{3}{*}{ Haryana } & A & 255 & 64.31 & $-10.55^{* *}$ & 87 & 28.39 & -7.38 & -167.5 & -4.22 \\
\hline & $\mathrm{P}$ & 208 & 71.15 & $-11.69^{* *}$ & 83 & 32.17 & -5.97 & -125.1 & -3.45 \\
\hline & $\mathrm{Y}$ & 780 & 20.77 & -1.27 & 958 & 12.94 & 1.53 & $177.8^{* *}$ & 2.61 \\
\hline \multirow{3}{*}{ Punjab } & A & 14.6 & 93.15 & $-13.84^{* *}$ & 2.7 & 28.15 & -1.37 & -11.93 & -2.26 \\
\hline & $\mathrm{P}$ & 12 & 84.17 & $-12.74^{* *}$ & 3.39 & 30.38 & 1.08 & -8.56 & -3.55 \\
\hline & Y & 867 & 12.00 & $1.27^{* *}$ & 1256 & 7.73 & $2.50^{*}$ & $388.7^{* *}$ & 8.56 \\
\hline \multirow{3}{*}{ Uttar Pradesh } & A & 889 & 20.02 & $-3.61^{* *}$ & 584.9 & 3.69 & 0.37 & -303.6 & -7.09 \\
\hline & $\mathrm{P}$ & 780 & 22.18 & -0.99 & 549 & 21.86 & $-3.8^{* *}$ & -231.3 & -3.23 \\
\hline & $\mathrm{Y}$ & 876.3 & 9.52 & -0.19 & 940 & 22.02 & -4.42 & 64 & 1.24 \\
\hline \multicolumn{10}{|l|}{ Southern Zone } \\
\hline \multirow{3}{*}{ Andhra Pradesh } & $\mathrm{A}$ & 245 & 73.47 & $14.27^{* *}$ & 581.9 & 15.33 & -4.51 & $336.9^{* *}$ & 4.70 \\
\hline & $\mathrm{P}$ & 264 & 97.73 & $20.27^{* *}$ & 718 & 22.28 & -6.04 & $454^{* *}$ & 4.32 \\
\hline & Y & 908 & 35.90 & $5.25^{* *}$ & 1230 & 14.63 & -1.61 & $322^{* *}$ & 2.45 \\
\hline \multirow{3}{*}{ Karnataka } & A & 386 & 32.90 & $5.73^{* *}$ & 901 & 10.85 & 2.58 & $514.9^{* *}$ & 9.61 \\
\hline & $\mathrm{P}$ & 192.9 & 42.92 & $8.11^{* *}$ & 566 & 22.79 & 7.40 & $372.7^{* *}$ & 8.63 \\
\hline & Y & 487 & 21.15 & $2.25^{* *}$ & 622 & 15.37 & 4.70 & $135.4^{* *}$ & 3.00 \\
\hline \multicolumn{10}{|l|}{ Eastern Zone } \\
\hline \multirow{3}{*}{ Bihar } & A & 114.4 & 27.45 & $-3.03^{* *}$ & 177.8 & 24.02 & $10.32^{* *}$ & $63.7^{* *}$ & 4.12 \\
\hline & $\mathrm{P}$ & 107 & 30.09 & $-3.17^{* *}$ & 192.1 & 32.22 & $15.11^{* *}$ & $85.1^{* *}$ & 4.55 \\
\hline & Y & 941 & 12.43 & 0.14 & 1062 & 11.11 & $4.35^{* *}$ & $121.2^{*}$ & 2.31 \\
\hline \multirow{3}{*}{ Odisha } & A & 32.81 & 18.01 & -0.83 & 44.57 & 16.96 & $5.42^{*}$ & $11.77^{* *}$ & 4.14 \\
\hline & $\mathrm{P}$ & 20.11 & 25.26 & -0.69 & 33.54 & 24.45 & $8.42^{* *}$ & $13.43^{* *}$ & 4.98 \\
\hline & Y & 607.1 & 10.13 & 0.13 & 745.4 & 7.46 & $2.84^{* *}$ & $138.3^{* *}$ & 5.18 \\
\hline \multirow{3}{*}{ West Bengal } & A & 32 & 35.94 & $4.06^{* *}$ & 23.69 & 8.61 & $3.83^{* *}$ & -8.35 & -1.89 \\
\hline & $\mathrm{P}$ & 28.3 & 40.99 & $-5.19^{* *}$ & 26.94 & 12.69 & $5.19^{* *}$ & -1.35 & -0.30 \\
\hline & $\mathrm{Y}$ & 875 & 15.77 & 1.09 & 1134.3 & 4.66 & $2.00^{* *}$ & $258.9^{* *}$ & 4.78 \\
\hline \multicolumn{10}{|l|}{ Western Zone } \\
\hline \multirow{3}{*}{ Gujarat } & A & 122.2 & 47.87 & 1.64 & 192.3 & 20.96 & 4.49 & $70^{* *}$ & 2.89 \\
\hline & $\mathrm{P}$ & 93.5 & 63.10 & 3.36 & 212.9 & 29.87 & 7.19 & $119.4^{* *}$ & 4.45 \\
\hline & Y & 707 & 21.36 & $1.69^{*}$ & 1090 & 10.37 & 2.59 & $382.5^{* *}$ & 6.04 \\
\hline \multirow{3}{*}{ Maharashtra } & A & 816 & 27.94 & $4.07^{* *}$ & 1292 & 20.36 & 2.11 & $476^{* *}$ & 4.50 \\
\hline & $\mathrm{P}$ & 502 & 44.62 & $5.59^{* *}$ & 1048 & 30.73 & 1.94 & $546^{* *}$ & 4.83 \\
\hline & Y & 595 & 17.14 & $1.45^{*}$ & 799.4 & 12.18 & -0.17 & $204.5^{* *}$ & 4.55 \\
\hline \multirow{3}{*}{ Rajasthan } & A & 1314 & 41.93 & -3.04 & 1399 & 25.23 & 4.35 & 85 & 0.38 \\
\hline & $\mathrm{P}$ & 907 & 52.04 & -1.15 & 1134 & 35.01 & -3.44 & 227 & 1.12 \\
\hline & $\mathrm{Y}$ & 680 & 18.24 & -0.14 & 796 & 17.59 & 2.17 & $116.2^{*}$ & 2.03 \\
\hline Central Zone & & & & & & & & & \\
\hline & A & 2590 & 9.27 & $1.60^{* *}$ & 3290 & 4.10 & 0.43 & $700.8^{* *}$ & 7.22 \\
\hline Madhya Pradesh & $\mathrm{P}$ & 2228 & 16.61 & $1.53^{* *}$ & 3405 & 11.66 & 2.12 & $1177^{* *}$ & 7.00 \\
\hline & Y & 857.3 & 10.71 & 0.47 & 1034 & 9.96 & 1.70 & $176.7^{* *}$ & 4.19 \\
\hline & A & 6824 & 12.00 & 0.24 & 8627 & 8.16 & 1.74 & $1803^{* *}$ & 5.12 \\
\hline India & $\mathrm{P}$ & 5354 & 15.32 & 0.81 & 8024 & 11.12 & 2.41 & $2670^{* *}$ & 7.14 \\
\hline & $\mathrm{Y}$ & 782.8 & 6.94 & $0.57^{*}$ & 929.2 & 5.83 & 0.65 & $146.5^{* *}$ & 6.06 \\
\hline
\end{tabular}

** and *indicate significance at 1 and 5 per cent level respectively, $A=$ Area, $P=$ Production, $Y=$ Yield. 
zones while central, eastern and western zones also experienced significant impact. In contrast, no significant impact of the program has been observed in northern zones of India which was evident by net decline in area and production during NFSM-P period as compared with previous period. Similarly, coefficient of variation in area, production and yield decreased significantly after initiation of the program in all chickpea growing states excluding production in Bihar and yield in Uttar Pradesh. The coefficient of variation in yield of chickpea in all states before NFSM-P program ranged from 36 per cent to 10 per cent has reduced between 15 per cent and 5 per cent after the program. At all India level, significant impact of NFSM-P was noticed in chickpea area, production and yield and also in terms of decline in instability. The positive growth of 1.74 per cent per annum and 2.41 per cent per annum in area and production was marked after NFSM-P.

\section{(IV) Relative contribution of area and yield in production of chickpea during NFSM-P period}

During NFSM-P period, positive change of area under chickpea has contributed maximum of 49.38 per cent in change in chickpea production in India (Table 8). Similarly, yield of chickpea has contributed 43.29 per cent to total production where as interaction between area and yield has contribution of 7.33 per cent. Among the major chickpea growing states only Punjab, West Bengal and Gujarat experienced a fall in mean area of chickpea while fall in mean yield of chickpea was noticed only in Haryana. The remaining districts witnessed increase in mean area and yield under chickpea. The change in mean area contributed more than the change in mean yield towards chickpea production in Haryana, Andhra Pradesh, Karnataka, Bihar, Odisha, Maharashtra and Rajasthan whereas the change in mean yield contributed more than the change in mean area in chickpea production was noticed in Uttar Pradesh, Punjab, West Bengal, Gujarat and Madhya Pradesh. Further, it could be noticed change in mean area was the major source of increasing production in southern zone rather than change in yield after the start of NFSM-P.

\section{CONCLUSION}

It has been found that the Andhra Pradesh and Karnataka of the southern zone of India have been emerging as the niche area in chickpea cultivation whereas area under chickpea in Haryana, Punjab and Uttar Pradesh of northern zone has shown declining trend during the study period. After the

Table 8: Per cent contribution of area and yield to production of chickpea in major states of India during triennium ending 2008-09 over triennium average ending 2014-15

\begin{tabular}{|c|c|c|c|}
\hline States & Area Effect & Yield Effect & Interaction Effect \\
\hline \multicolumn{4}{|l|}{ Northern Zone } \\
\hline Haryana & 181.04 & -129.81 & 48.78 \\
\hline Punjab & -441.29 & 650.92 & -109.63 \\
\hline Uttar Pradesh & 42.90 & 55.96 & 1.14 \\
\hline \multicolumn{4}{|l|}{ Southern Zone } \\
\hline Andhra Pradesh & 65.86 & 37.64 & -3.50 \\
\hline Karnataka & 50.87 & 34.17 & 14.96 \\
\hline \multicolumn{4}{|l|}{ Eastern Zone } \\
\hline Bihar & 53.75 & 31.01 & 15.23 \\
\hline Odisha & 53.71 & 35.37 & 10.92 \\
\hline West Bengal & -6.36 & 107.75 & -1.38 \\
\hline \multicolumn{4}{|l|}{ Western Zone } \\
\hline Gujarat & -49.50 & 158.21 & -8.71 \\
\hline Maharashtra & 55.42 & 41.00 & 3.58 \\
\hline Rajasthan & 47.53 & 41.45 & 11.02 \\
\hline \multicolumn{4}{|c|}{ Central Zone } \\
\hline Madhya Pradesh & 40.47 & 50.36 & 9.17 \\
\hline India & 49.38 & 43.29 & 7.33 \\
\hline
\end{tabular}


initiation of NFSM-P, production has increased in major chickpea growing states and India as a whole but increase in production was contributed by area addition rather than yield improvement. This concludes productivity of chickpea has almost stagnant after NFSM-P program, reflecting need of improved yield varieties and strengthening other required logistic supports to achieve self-sufficiency in pulses production as a whole.

\section{REFERENCES}

Bantilan, M.C.S., Joshi, P.K. and Asokan, M. 1999. Silent chickpea revolution in non-traditional areas-some evidences from Andhra Pradesh. Indian J Agric Econ., 54: 533-544.

Chattopadhyay, C. and Mohapatra, S.D. 2014. Perception of constraints in chickpea production in India. Ind. J. Agric. Sci., 85: 287-289.
IIPR. 2015. E-Pulses Data Book, Indian Institute of Pulses Research, Government of India. (http://www.iipr.res. in/e-pulse-data-book-state-wise.html)

Mohanty, S. and Satyasi, K.J. 2015. Feeling the pulse. Rural Pulse, Department of Economic Analysis and Research, Mumbai, India.

Suhasini, P., Kiresur, V.R., Rao, G.D.N. and Bantilan, M.C.S. 2009. Adoption of chickpea cultivars in Andhra Pradesh: Pattern, trends and constraints. Research report for tropical legumes-II submitted to ICRISAT, Andhra Pradesh, India, pp. 10-12. 
